\title{
IS A CLOSED SYSTEM OF LEGAL STANDING ALWAYS SAFE FOR THE ENVIRONMENT? \\ THE CASE OF ARMENIA
}

\author{
GOR MOVSISIAN* \\ Lecturer \\ Yerevan State University (Armenia) \\ gormovses@gmail.com
}

Received: 23 August 2013 / Accepted: 26 November 2013

\begin{abstract}
The objective of this note is to provide solutions to the problem of the legal standing of non-governmental organizations before the courts in the particular case of Armenia. These solutions are based on the progress that has been made in the study of environmental law, the provisions of the Constitution of Armenia, international obligations, and developments in case law. In particular, it is argued that nongovernmental organizations in Armenia are formally endowed with the right to access justice on environmental matters in public interest litigations, even though this right is not recognized by the courts of the Republic of Armenia. To overcome this discrepancy the author of the article offers an interpretation of the legislation in order to sustain his position. By analysing some problems the author underlines the prominence of the developments in the Republic of Armenia and Europe that are little known to the lawmaking and law enforcing authorities or underestimated by them in the long term perspective.
\end{abstract}

RESUM: L'objectiu d'aquest treball és proporcionar solucions al problema de la legitimació activa de les organitzacions no governamentals, tot centrant-se en el cas armeni. Aquestes solucions es basen en el progrés fet en l'estudi del dret ambiental, les

Gor Movsisian holds a $\mathrm{PhD}$ degree in Environmental Law and works as a research fellow at the Environmental Law Research Center of Yerevan State University, Faculty of Law. 
previsions de la Constitució armènia, les obligacions internacionals contragudes per la mateixa República d'Armènia i els desenvolupaments jurisprudencials. En particular, es defensa que a les organitzacions no governamentals a Armènia se'ls reconeix formalment el dret d'accés a la justícia en matèria ambiental en el cas de litigis d'interès públic, encara que els tribunals armenis no ho acostumin a entendre així. Per superar aquesta discrepància, l'autor de la nota ofereix una interpretació de la legislació per sostenir la seva posició. D'acord amb l'anàlisi d'alguns problemes, l'autor subratlla la importància dels desenvolupaments legislatius a la República d'Armènia i Europa, que són poc coneguts pels operadors jurídics o, almenys, subestimats per ells.

RESUMEN: El objetivo de este trabajo es proporcionar soluciones al problema de la legitimación activa de las organizaciones no gubernaentales, centrándose en el caso armenio. Estas soluciones se basan en el progreso realizado en el estudio del Derecho ambiental, las previsiones de la Constitución armenia, las obligaciones internacionales contraidas por la propia República de Armenia y los desarrollos jurisprudenciales. En particular, se defiende que a las organizaciones no gubernamentales en Armenia se les reconece formalmente el derecho de acceso a la justicia en materia ambiental en el caso de litigios de interés público, aunque los tribunales armenios no lo acostumbren a entender así. Para superar esta discrepancia, el autor de la nota ofrece una interpretación de la legislación para sostener su posición. De acuerdo con el análisis de algunos problemas, el autor subraya la importancia de los desarrollos legislativos en la República de Armenia y Europa, que son poco conocidos por los operadores jurídicos o, al menos, subestimados por ellos.

KEYWORDS: Access to justice in environmental matters — legal standing — nongovernmental organizations - Republic of Armenia.

PARAULES CLAU: Accés a la justícia en matèria de medi ambient — legitimació processal — organitzacions no governamentals — República d'Armènia. 
PALABRAS CLAVE: Acceso a la justicia en materia de medio ambiente legitimación procesal — organizaciones no guvernamentales — República de Armenia.

Summary: I. Preface. II. A closed system of legal standing. III. Legal standing of the NGOs according to the Armenian courts. IV. Possible future developments for NGOs legal standing in environmental matters in Armenia. 1. What are the minimum requirements of the Aarhus convention applicable in the legal system of Armenia to provide access to justice for NGOs in environmental matters? 2. What are the current trends of lawmaking in Europe, Central Asia and South Caucasus? 3. How does the system that protects human environmental rights interconnect with the system established under the European Convention of Human Rights from the perspective of the national legal system? 4. What is the hierarchy and influence of judicial acts on the overall legal practice of Armenia? 5. What are the possible alternatives? V. Conclusion. VI. Bibliography.

\section{PREFACE}

The process of shaping the rule of law will last for decades in the Republic of Armenia. Although it will require changes in individual mentality, it is the best way of securing a well-shaped legal system. Power is an organic phenomenon that embodies a comprehensive and integrated expression of progressive and regressive aspects, which society largely perceives through the legal system. Indeed, for a society struggling to ensure the rule of law it is crucial that the executive branch adheres to the law, because there is the possibility of abuse and accumulation of power. The present analysis should under no circumstances be perceived as an endorsement of recent criticism of the Armenian judiciary from apparently spontaneous social movements. However, society's perception of constant violations of the rule of law by the courts is vivid, even if the causes are not well established ${ }^{1}$ (especially the interconnected nature of these causes). The aim of my analysis of this topic is to go beyond a superficial assessment of the activities of judicial and executive branch.

\section{A CLOSED SYSTEM OF LEGAL STANDING}

The economic crisis is bringing with it a process of removing environmental protection mechanisms in legislation, particularly in societies that have no serious possibilities of taking rational choices in the political arena, for a variety of complex reasons. ${ }^{2}$

\footnotetext{
${ }^{1}$ Our research on these causes is in process of completion and will be made available later in another form.

${ }^{2}$ Insufficient level of economic development and legal consciousness, lack of legitimacy of power, weak mechanisms to guarantee social relevance of expertise, etc.
} 
Recently, when defending my $\mathrm{PhD}$ thesis on the legal regime of public intervention in the management of nature resources in Armenia ${ }^{3}$ I came to the following conclusion: "The provisions of environmental legislation within the overall system of Armenian legislation stand out for the low level of their quality (from substantial ambiguity to non-compliance with the rules of legal technique, e.g. Law draft 'On the amendments and addendums to the Law of the Republic of Armenia (henceforth RA Law) on environmental impact expertise'), also caused by the closed system between license holders and executive power." Currently we are facing a situation in which a significant number of executive decisions (particularly, the Ministry of Nature Protection, Ministry of Energy and Nature Resources, Ministry of Healthcare, etc.) granting the right to use nature resources are excluded from judicial review because of the "absence of entities" capable of challenging their decisions (or omissions) before the courts. Consequently, there is a situation of non-compliance with the constitutional order, particularly article 5 of the Constitution of Armenia. ${ }^{4}$ The circumstances described certainly affect the overall social surveillance in the legal regulatory mechanism of society.

A comprehensive idea of human environmental rights was only introduced into Armenia in 2005 by means of an amendment of the Constitution that added a new article (33.2). This article stipulates that everyone has the right to a healthy environment and to environmental information (although it is not conceived literally as a right, but as the public authority's obligation to disseminate environmental information). Furthermore, everyone has the right of access to effective legal remedies in order to protect constitutional rights and freedoms before courts and other public authorities (article 18). Even so, despite such complete constitutional recognition of environmental rights, the legal solutions to real life situations are much more complex to cope with than general legal provisions or even international obligations. ${ }^{5}$

\footnotetext{
${ }^{3}$ MOVSISIAN, G., Legal Regulation of State Governance of Natural Resources in the Republic of Armenia, PhD Thesis in Law, Yerevan, 2012.

4 "The state power shall be exercised in conformity with the Constitution and the laws based on the principle of the separation and balance of the legislative, executive and judicial powers" (Constitution of the Republic of Armenia (adopted on 27 November 2005), Special Edition of Official Bulletin of the Republic of Armenia).

${ }^{5}$ With this approach we do not object to the importance of comprehensive, encyclopedic knowledge of social processes in lawmaking. However, the process in Armenia mainly disregards this kind of experience so it may be considered antiscientific.
} 
Without going into the debate on the "resource curse" hypothesis, ${ }^{6}$ which in my opinion mainly concerns the interrelation of people's sovereignty and state sovereignty (with the natural privilege of people's sovereignty), I should point out that ordinary Armenian citizens cannot enjoy their right to a healthy environment and to use natural resources, partly because of its "classical vagueness". Given this, in the last six years nongovernmental organizations (NGOs) have asked the courts to revoke and invalidate administrative decisions violating the human right to a healthy environment.

The first question posed by both main actors in the legal process of licensing the use of natural resources (license holder and government) was why an NGO should have the right to challenge administrative acts, omissions and decisions of the executive bodies, given the fact that its substantive rights are not affected by them? ${ }^{7}$ Facing up this question the Cassation Court of the Republic of Armenia had overcome apparently the alleged closed system of legal standing in environmental matters in its Decision of 30 October $2009 .{ }^{8}$ Indeed, the further strengthening of the Cassation Courts' position would mark a new era for the maturity of human environmental rights in Armenia. I would go so far as to say that this new era would have the same significance as the ratification by Armenia of the United Nations Economic Commission for Europe (UNECE) Convention on access to information, public participation and access to justice in environmental matters (the Aarhus Convention) ${ }^{9}$ or to the recognition of human environmental rights in the Armenian Constitution. However, our discussion of the situation below after the aforementioned Decision does not allow us to be so optimistic, and the beginning of a new era in this domain may now only be a possibility.

\footnotetext{
${ }^{6}$ For more on this debate, see VIÑUALES, J. E., "The resource curse - a legal perspective", Global Governance, 2010, available in <http://papers.ssrn.com/sol3/papers.cfm?abstract_id=1652739> (Last retrieved, 7 December, 2012).

${ }^{7}$ Human environmental rights are third generation rights and mostly individual. In the meantime, for example, the enjoyment of the right to a healthy environment is linked to the quality of natural resources, any changes in which presume negative consequences (violation of the right) for a wide range of entities at different levels - local, national and international. Having in regard this kind of content of the right the possibility to claim protection of the right is conferred to non-governmental organizations as representatives of collective interests in specific spheres.

8 VD/3275/05/08, 30 October, 2009, "Transparency International Anti-Corruption Center" NGO, "Ecodar" NGO v. the Government of the Republic of Armenia, the Ministry of Nature Protection of the Republic of Armenia, the Ministry of Energy and Nature Resources of the Republic of Armenia, and, as a third party, "Armenia Copper Program" CJSC, available in <http://www.datalex.am> (Last retrieved on 30 May, 2012).

9 UNECE Convention on access to information, public participation and access to justice in environmental matters, available in $<\mathrm{http}$ :/www.unece.org/env/pp/treatytext.html $>$ (Last retrieved on 30 May, 2012).
} 


\section{LEGAL STANDING OF NGOS ACCORDING TO THE ARMENIAN COURTS}

In its aforementioned decision of 30 October 2009, the Cassation Court of Armenia reversed a decision of the Administrative Court of the Republic of Armenia for the first time and deemed that the appeal of an NGO against the rejection of its legal standing in an environmental protection case is receivable. ${ }^{10}$ In its argumentations and conclusions, the Cassation Court of Armenia stated the following; "Ecodar' NGO is an entity established in accordance with the RA Act on Non-Governmental Organizations". It meets the requirements of national law and promotes environmental protection in accordance with the mission and objectives established in its charter. Consequently the Cassation Court of Armenia considers "Ecodar" NGO a concerned organization in the sense of the Aarhus Convention, and it possesses the right to access justice before the courts in environmental matters. To come to this conclusion the Cassation Court refers merely to the Act on Non-Governmental Organizations, ${ }^{11}$ to the provisions of the Aarhus Convention, particularly regarding articles 3 and 79 of the Code of Administrative Procedure of the Republic of Armenia ${ }^{12}$ (hereinafter RA CAP).

According to the requirements of RA CAP on the implementation of the Cassation Court's judgements (Chapter III), the Administrative Court is vested only with the authority to examine the case merits: namely, the substantive issues of the case. However, the Administrative Court of Armenia ignored the requirements of the legislation and referred once again to the procedural issues of the case, particularly the legal standing of NGOs, in its Decision of 24 March, 2010. Because any comments on the subject and the background of the appeal are superfluous, I would like to move straight on toargue that there is a violation of article 3 of the Constitution of Armenia, stating that "[s]tate and local self-government bodies and public officials are competent to perform only such acts for which they are vested in by Constitution or laws."

\footnotetext{
${ }^{10}$ VD/3275/05/09, 28th July, 2009, “Transparency International Anti-Corruption Center” NGO, "Ecodar” NGO $v$. the Government of the Republic of Armenia, the Ministry of Nature Protection of the Republic of Armenia, the Ministry of Energy and Nature Resources of the Republic of Armenia, and, as a third party, "Armenia Copper Program" CJSC, available in <http://www.datalex.am> (Last retrieved on 30 May, 2012).

11 Adopted on 04 December, 2001, Entered into force on 27 December, 2001, Official Bulletin of RA 2001.12.27/42(174), art. 1034.

12 Adopted on 28 November, 2007, Entered into force on 01 June, 2008, Official Bulletin of RA 2007.12.19/64(588), art. 1300.
} 
The developments take a different route just after the aforementioned Decision of the Administrative Court of Armenia. The Cassation Court of Armenia reviewed the appeal brought against that Decision and concluded that it should not be upheld. ${ }^{13}$ In general, the new Decision of the Cassation Court of Armenia lacked any grounds and contained only references to: 1) the RA CAP, 2) the Decision of the Cassation Court of Armenia of 30 March 2010, and 3) Decision N 906 of the Constitutional Court of Armenia.

Before the Decision of the Cassation Court of Armenia of 1 April 2011 the phrase "his/her" following the word "breach" of the article 3 RA CAP was submitted to the consideration of the Constitutional Court of Armenia. On this issue, the Constitutional Court Decision N $906^{14}$ stated the following:

"1. Considering the role that NGOs play in the development of state and civil society and in an attempt to increase the efficiency of their activities, the Constitutional Court of Armenia finds that the RA CAP may encompass the occasions of bringing cases before the court by concerned NGOs (on the basis of the Charter) for the purpose of protecting public interest. For this reason, the current developments of the institution of actio popularis in Europe should be taken into consideration. This kind of regulation will both promote the protection of violated rights and lawful interests, and increase the role of NGOs as a substantive part of civil society.

2. The actio popularis should be excluded when there is a lack of sufficient interest. The Constitutional Court concludes that for the purpose of increasing the effectiveness of social control over the state and local authorities, and to guarentee the implementation of the main functions of NGOs any further law-making developments should take into account the stated legal position of the Court."

At the same time the Constitutional court concludes the compliance of the article 3 of the RA CAP to the Constitution of Armenia. I share the position of the Constitutional Court, because recognizing the phrase "his/her" in the article 3 unconstitutional will lead to the unconstitutionality of the whole procedural system establishing the right to access the justice in the Armenian Administrative Court.

\footnotetext{
13 VD/3275/05/09, 1 April 2011, "Ecodar" NGO v. the Government of the Republic of Armenia, the Ministry of Nature Protection of the Republic of Armenia, the Ministry of Energy and Nature Resources of the Republic of Armenia, and, as a third party, "Armenia Copper Program" CJSC, available at $<$ http://www.datalex.am> (Last retrieved on 30 May, 2012).

14 RA Constitutional Court Decision N 906, 7 September 2009, available at $<$ http://www.armlaw.am> (Last retrieved on 30 May, 2012).
} 
The decision of the Constitutional Court would have been a step towards solving the problem of the legal standing of NGOs, if the Court had discussed the compliance of article 3 with articles 18 and 19 of Constitution so that NGOs could be provided with access to justice in the specific field of environmental protection. This is so because for environmental cases the constitutional framework is formed through human environmental rights and constitutional principles about correlation of national and international legal systems.

To put an end to the aforementioned controversial developments in case law, and at the request of the Human Rights Defender, the Council of Court Chairmen of Armenia (CCC) issued Decision N 127 (On the practice of implementation of article 79 of the Armenian Code of Administrative Procedure), which states: "The natural and legal entities are not deemed to have the right to challenge any administration. Their standing is based solely on their interest in the lawfulness of the activities of administrative bodies". Decision N 127 of CCC states the following: "The European Commission for Democracy through Law (Venice Commission) has the following opinion on the subject: 'All entities have the right to challenge a Decision if their rights have been infringed. If the Decision does not directly infringe the rights of a particular entity, whether this entity can challenge the decision is left to national legislation." The CCC also felt it necessary to highlight the case law of the European Court of Human Rights (ECHR): "In its judgements, the ECHR stated that the dispute should be real and precise in nature. The content of the action should refer to rights and obligations, and the possible resolution of the dispute should have direct consequences on the protected rights and obligations (Le Compte, Van Leuven and De Meyere v. Belgium. App. No. 6878/75, para. 47; Ringeisen v Austria, app. No. 2614/65, para. 94; Benthem v The Netherlands, app. No 8848/80, para. 32)". ${ }^{15}$

Throughout this process the various Armenian judicial bodies involved have given a wide range of opinions, some of which were subjective or even ridiculous (e.g., "nongovernmental organizations operating with financial support of donor organizations should have no access to justice" or "the judicial system in Armenia is totally corrupted"). Putting such considerations to one side and considering the achievements

\footnotetext{
${ }^{15}$ Council of Courts' Chairmen of Armenia Decision N 127, available in $<$ http://www.court.am $>$ (Date of recuperation 30 May, 2012).
} 
of Armenian environmental law, the Armenian Constitution, international law applied to Armenia and developments in case law, I conclude that:

1) From a legal point of view - in a narrow formal sense - non-governmental organizations in Armenia are endowed with the right to bring cases before a court to protect public environmental interests,

2) In the meantime, the way in which NGOs can take part in the decision-making process should be specified in the legislation as a criterion for their legal standing.

\section{POSSIBLE FUTURE DEVELOPMENTS FOR NGOS LEGAL STANDING IN ENVIROMENTAL MATTERS IN ARMENIA}

Various issues related to the legal standing of NGOs in environmental matters will be discussed below. I leave it up to the reader to interpret the discussion.

\section{What are the minimum requirements of Aarhus Convention applicable in the legal system of Armenia to provide access to justice for NGOs in environmental matters?}

By virtue of article 6, paragraph 4 of the Armenian Constitution, international treaties are a constituent part of the legal system of the Republic. If a ratified international treaty stipulates norms that are different from those of national law, the treaty shall prevail. International treaties that do not comply with the Constitution cannot be ratified. It should be mentioned that the extent to which international treaties influence Armenian law has not been sufficiently scrutinized by scholars. In a commentary on the Constitution the author has proven that it requires the provisions of international treaties to be obligatorily enforced by the public authorities and their employees. ${ }^{16}$ In line with the ideas of Alfred Verdross ${ }^{17}$ and Charles Hide, ${ }^{18}$ the provisions of international treaties must be applied to regulate both international and national relations.

\footnotetext{
${ }^{16}$ KOCHARIAN, V., Commentaries to the Constitution of the Republic of Armenia, Yerevan, 2010, p. 106.

${ }^{17}$ VERDROSS, A., International Law, Moscow, 1959.

${ }^{18}$ HYDE, C. International Law Chiefly as Interpreted and Applied by the United States (I), Moscow, 1950.
} 
The Armenian experience shows, then, that the provisions of international treaties are mostly complied with in law making but not in law enforcement in which the European Convention on human rights and fundamental freedoms ${ }^{19}$ (hereinafter European Convention) prevails over national law. In fact, between 2007 and 2011 the Cassation Court of Armenia directly applied the European Convention to approximately 70 cases, ${ }^{20}$ although it cannot prevail over stricter international law provisions. Likewise, in the sphere of environmental protection, decision makers mostly take treaties into account when drafting legal documents. ${ }^{21}$ The case law in this field can be summarized in the following statistics:

1) Cases on administrative liability: approximately 137 decisions between 2008 and 2011.

2) Litigations between the license holders and public authorities: approximately 46 judicial decisions between 2008 and $2011^{22}$

The experience gained in the transposition of the European Union directives has revealed valuable problem-solving strategies in this field. The obligation of consistent interpretation (also referred to as the doctrine of direct effect) was first established by the ECJ in the von Colson and Kamann case $\mathrm{e}^{23}$ to ensure that EU directives should have effect despite the absence of proper transposition. ${ }^{24}$ This means that the courts of the Member states apply those provisions of EU directives that are unconditional and sufficiently clear, irrespective of any "individual rights". However, this effect is worthless if it cannot be initiated. ${ }^{25}$ This may be an interesting lesson for Armenia and requires further research. If possible Armenian courts should apply the provisions of

\footnotetext{
${ }^{19}$ European Convention on human rights and fundamental freedoms, 4 November 1950, Rome, available at $<$ http://www.hri.org/docs/ECHR50.html> (Last retrieved on 30 May, 2012).

${ }^{20}$ The data are available at <http://www.armlaw.am> (Last retrieved on 30 May, 2012).

${ }^{21}$ E.g. drafts of environmental internal regulations, available at $<$ http://www.mnp.am/?p=306> (Last retrieved on 30 May, 2012),

${ }^{22}$ The data are available at $<$ http://www.armlaw.am> (Last retrieved on 30 May, 2012).

${ }^{23}$ Case 14/83 Sabine von Colson and Elisabeth Kamann v. Land Nordrhein-Westfalen [1984] ECR, 1891.

${ }^{24}$ BACKES, C., ELIANTONIO, M., "The influence of the ECJ's case law on indirect effect in the Italian, German, Dutch and English administrative legal systems and its application by the national administrative courts", p. 1, 2009, available in $<$ http://ssrn.com/abstract $=1427255>$.

${ }^{25}$ DARPÖ, J., "Justice through Environmental Courts? Lessons Learned from the Swedish Experience", p. 13, available at $<$ http://www.jandarpo.se/inenglish.asp $>$ (Last retrieved on 25 July, 2012).
} 
international treaties in such a way that their amorphous conditions in the Armenian legal system are overcome.

According to Decision VD3275/05/09 of the Administrative Court, paragraph 3 of Article 9 of the Aarhus Convention does not confer the right to access justice. For the Court it only establishes an obligation on the Parties of the Convention and does not directly grant any rights to NGOs. Apparently, the Administrative Court of Armenia is correct, given paragraph 2 of article 9 of the Convention, which states the following:

"2. Each Party shall, within the framework of its national legislation, ensure that members of the public concerned

(a) Having a sufficient interest or, alternatively,

(b) Maintaining impairment of a right, where the administrative procedural law of a Party requires this as a precondition,

have access to a review procedure before a court of law and/or another independent and impartial body established by law, to challenge the substantive and procedural legality of any decision, act or omission subject to the provisions of article 6 and, where so provided for under national law and without prejudice to paragraph 3 below, of other relevant provisions of this Convention. What constitutes a sufficient interest and impairment of a right shall be determined in accordance with the requirements of national law and consistently with the objective of giving the public concerned wide access to justice within the scope of this Convention. To this end, the interest of any non-governmental organization meeting the requirements referred to in article 2 , paragraph 5 , shall be deemed sufficient for the purpose of subparagraph (a) above. Such organizations shall also be deemed to have rights capable of being impaired for the purpose of subparagraph (b) above."

The provisions of this paragraph do not exclude the possibility of a preliminary review procedure before an administrative authority and do not affect the requirement of exhaustion of administrative review procedures prior to recourse to judicial review procedures, where such a requirement exists under national law.

The provision does not state that members of the public can file lawsuits if permitted by national law. Instead, it grants the right to sue or complain and then permits parties to lay down "criteria" if they wish to do so. If specific criteria are not laid down in national law, the logical interpretation is that members of the public are deemed to have the right 
to go to court or to an administrative body. ${ }^{26}$ Depending on how narrowly they choose to define "sufficient interest" or "right", then, countries do not seem to be prevented from continuing to have restrictive standing rules. ${ }^{27}$ Therefore, the Convention enables the legal standing of NGOs to be narrowed from actio popularis to more restrictive criteria, when sufficient interest is alleged.

If domestic law does not provide any restrictive criteria, actio popularis seems to be possible. According to its Constitution, Armenia is a case in point because the principle of wide-ranging access to justice is specified in the Preface and article 9 of the Convention. For this reason, it seems to make no sense to narrowly interpret the Convention's provisions and suggest that it is up to the Party's law-making policy to decide whether the NGOs have the right to access justice. The right to access justice is conferred to NGOs by the ratification of the Aarhus Convention and the Armenian Constitution provides no reason to limit it.

In order to fully understand the process of implementing the provisions of the Aarhus convention in various legal cultures we need to refer to the case law of the Convention's Compliance Committee. Particularly, in Austrian case ACCC/C/2010/48 the communicant alleged that the scope of standing for individuals to challenge a permit (in the context of the EIA and IPPC procedures) under article 6 is limited to grounds related to "legal interest" and that "neighbors" may challenge the permitting procedure only to the extent that the activities affect their "private well-being" or their property, but "not the environment as such" and not the "correct application of environmental law". The Party concerned agrees that standing is restricted to "legal interest". It does not mean that the restriction to "a legal title or interest" in Austria prevents a person that wants to advocate a general public interest from having standing. In its recommendations and findings the Committee states:

"In the view of the Committee, outside the scope of the EIA and IPPC procedures and environmental liability, the conditions laid down by the Party concerned in its national law are so strict that they effectively bar NGOs from challenging acts or omissions that contravene national laws relating to the environment (cf. findings in

\footnotetext{
${ }^{26}$ BONINE, J. E., "The public's right to enforce environmental law", in Stec, S. (ed.) Handbook on Access to Justice under the Aarhus Convention., Szentendre, Hungary, March 2003, p. 32.

27 KRAVCHENKO, S., "The Aarhus Convention and Innovations in Compliance with Multilateral Environmental Agreements", Colorado Journal of International Environmental Law and Policy, vol. 18, n. 1, p. 40-41, available at $<$ http://ssrn.com/abstract=1076746>.
} 
previous cases referred to in paras. 69 and 70 above). The fact that there is a possibility that the procedure laid down under the sectoral environmental laws may be consolidated in the framework of the EIA or IPPC procedure for the purposes of a large project or that environmental liability and civil law remedies may apply, under conditions, does not compensate for the failure to fulfill the requirements of article 9, paragraph 3, concerning other acts and omissions (paragraph 73)."

Therefore, the Committee found that the Party concerned, in not ensuring the standing of environmental NGOs to challenge acts or omissions of a public authority or a private person in many of its sectorial laws, is not in compliance with article 9, paragraph 3, of the Convention. ${ }^{28}$ In the case $\mathrm{ACCC} / \mathrm{C} / 2008 / 33$, related to the United Kingdom, the Committee noted that the "Aarhus Convention article 9, paragraph 2 addresses both substantive and procedural legality. Hence, the Party concerned has to ensure that members of the public have access to a review procedure before a court of law and/or another independent body established by law which can review both substantive and procedural legality of decisions, acts and omissions in appropriate cases. ${ }^{29}$

The EU court has had a specific impact on developments in access to justice issues in environmental matters. Of particular note is the following preliminary ruling of the EU Court (Fourth Chamber) of 12 May 2011:

\begin{abstract}
"National legislation cannot limit the opportunity to appeal decisions likely to have significant effects on the environment to those alleging impairment of an individual interest, rather than a public interest, when the claimant alleges infringement of a law flowing from EU environment law. The CJEU examined Article 10a of the EU EIA Directive, which requires Member States to allow members of the public concerned who either have a sufficient interest or maintain an impairment of a right to have access to a judicial appeals process. They must be allowed to challenge the legality of decisions on matters for which the opportunity for public participation is required under that EU Directive. Further, Article 10a states that national legislation defining sufficient interest and impairment of a right must be consistent with the objective of giving the public concerned "wide access to justice". Although the provision leaves the Member States a significant discretion to
\end{abstract}

\footnotetext{
${ }^{28}$ Findings and Recommendations of the Aarhus Convention Compliance Committee with regard to communication ACCC/C/2010/48 concerning compliance by Austria. Adopted by the Compliance Committee on 16 December 2011.

29 Findings and Recommendations of the Aarhus Convention Compliance Committee with regard to communication ACCC/C/2008/33. Adopted by the Compliance Committee on 24 September 2010.
} 
determine what constitutes impairment of a right and other conditions for the admissibility of actions of individuals, the same is not true for the environmental non-governmental organizations meeting the requirements referred to in Article 1(2) of EU Directive 85/337. They are to be deemed to have sufficient interest and rights capable of being impaired in rules which are precise and not subject to other conditions. Therefore, non-governmental organizations promoting environmental protection should have a right to rely before the courts, in an action contesting a decision authorizing projects 'likely to have significant effects on the environment' for the purposes of Article 1(1) of EU Directive 85/337, on the infringement of the rules of national law flowing from Article 6 of the EU Habitats Directive, even where, on the ground that the rules relied on protect only the interests of the general public and not the interests of individuals, national procedural law does not permit this. The CJEU concluded that Article 10a of the EU EIA Directive precludes national legislation that does not allow environmental NGOs to bring a development permit appeal alleging a violation of a rule flowing from EU environmental law, if the reason for not allowing the appeal is that rule protects only the public interest and not an individual interest". ${ }^{30}$

In this context I would like to hold back on some speculations on the flood of claims and over-burdening of the courts. For the moment I will present some data of the Armenian experience. According to the official report of the Ministry of Nature Protection, 159 projects in 2010 passed the environmental impact assessment and 80 applications for environmental information were submitted. ${ }^{31}$ If we assume that half of the cases (which is merely impossible) are finally submitted to the courts, overall there will be 120 cases on two procedural environmental rights. It should be remembered that in 2011 the Administrative Court reviewed 6230 applications, only 1106 of which challenged the decisions, acts and omissions of public authorities. ${ }^{32}$ The Ministry of Nature Protection appeared as a defendant in only 8 cases in 2010. These numbers once again show that any talk of over-burdening the courts has little foundation. Undoubtedly

\footnotetext{
${ }^{30}$ Decision of the European Court of Justice (Fourth Chamber). Preliminary ruling under Article 234 EC, | from the Oberverwaltungsgericht für das Land Nordrhein-Westfalen (Germany), in Case C-115/09, 12 May, 2011.

${ }^{31}$ The press release of the Ministry of Nature Protection of RA on the activities implemented within 2010, p. 5, available at $<$ http://www.mnp.am/?p=168 $>$ (Last retrieved on 22 August, 2012).

${ }^{32}$ The Report on the Course of Administrative Cases in the RA Administrative Court in 2010, available at $<$ http://www.court.am/?1=lo\&id=224\&cat_id $=0 \&$ page_num $=2>$ (Last retrieved on 1 February, 2012).
} 
the best way to avoid unsubstantiated claims is still to allow the courts to decide, not to deprive people of access to justice.

\section{What are the current trends of lawmaking in Europe, Central Asia and South Caucasus?}

The trends in legislating the legal standing of groups and NGOs in Europe are sometimes controversial for their progressive or regressive nature. Consequently the prominent EU Directive on access to justice remains a draft. ${ }^{33}$ However, the sectoral EU directives, such as the EU EIA directive, provide a variety of mehanisms for allowing access to justice in environmental matters.

In Netherlands the actio popularis was abolished and the criterion of "interested party" was introduced. ${ }^{34}$ In Austria, non-profit NGOs that have been in existence for three years, whose charter-specified aim isto protect the environment, and which have participated in the initial government hearing about a project have standing to appeal. ${ }^{35}$ More liberal regimes on legal standing are provided by the legislation of such European countries as Portugal, Slovenia, Estonia, etc. ${ }^{36}$ Particular attention should be paid to the experience of the Federal Republic of Germany, as the system of administrative justice in Armenia is built on the principals of the German one. Despite the German Federal Natural Conservation Act, which entered into force in 1976, it was only in 2002 that para. 61 was introduced to provide limited rights to take representative action in environmental matters. ${ }^{37}$

The opportunities for NGOs to involve themselves in legal procedure differ considerably between EU member states, although even the most restrictive states make special arrangements for environmental associations. ${ }^{38}$ The situation differs somewhat

33 EU Directive on access to justice, available at $<$ http://www.ecba.org/content/index.php?option=com_content\&view=article\&id=557:measurec\&catid=94:procedural-safeguards-measure-c\&Itemid=123> (Last retrieved 30 May, 2012).

${ }^{34}$ VERSCHUUREN, J., "The Role of the Judiciary in Environmental Governance in The Netherlands", 2007 , p. 5, available at $<$ http://ssrn.com/abstract $=1291263>$.

35 PRING, G., PRING, C., Greening Justice: Creating and Improving Environmental Courts and Tribunals, 2009, p. 37.

${ }^{36}$ Id. at 37 .

${ }^{37}$ German Advisory Council on the Environment, Access to justice in environmental matters: The crucial role of legal standing for non-governmental organizations, Statement, No 5, February 2005, pp. 6-7.

${ }^{38}$ EBBESSON, J., “Access to Justice in Environmental Matters in the EU”, 2002, p. 29. 
in Central Asia, Caucasus and Eastern Europe, where the problems in this field have been underlined by a UNECE study. ${ }^{39}$ Only in three countries ${ }^{40}$ of twelve natural entities and unions possess the right to apply to the court in the name of an indefinite number of persons. Indeed the data of the survey are mainly derived from legislation and research into case law developments is still on the agenda of the Aarhus Convention Task Force on Access to Justice.

\section{How does system that protects human environmental rights interconnect with the} mechanism established under the European Convention of Human Rights from the perspective of the national legal system?

Analysis of case law and particularly the CCC Decision of N 127 makes it clear that of the legislation governing the right to fair trial in the Republic of Armenia is being built on the basis of the provisions of the European Convention on Human Rights and, in particular, on the case law of the European Court of Human Rights. The European Convention is undoubtedly an almost complete panorama of fundamental human rights, though this does not imply that it aims for absolute uniformity. Human environmental rights are regarded as a third generation of human rights that are not reflected in the text of the European Convention. Despite this, as a result of systematization and the analysis of rich empirical data, professors of environmental law have shown that several judgments of the European Court pertain to environmental protection issues. ${ }^{41}$

Of course the nature of the appeals and the organic interrelation among different socioeconomic rights are crucial. Nevertheless, article 34 of the European Convention has a lot to say on this subject. Among other things it states:

"The Court may receive applications from any person, non-governmental organization or group of individuals claiming to be the victim of a violation by one of the High Contracting Parties of the rights set forth in the Convention or the

\footnotetext{
39 LAEVSKAYA, E., SKRYLNIKOV, D., Access to justice in environmental matters: available remedies, timelines and costs (Eastern Europe, Caucasus and Central Asia), 2012, pp. 6.

${ }^{40}$ Kyrgyzstan, Moldova, Tadjikistan.

41 KRAVCHENKO, S., BONINE, J. E. "Interpretation of Human Rights for the Protection of the Environment in the European Court of Human Rights", Global Business and Development Law Journal/, vol. 25, 2012.
} 
Protocols thereto. The High Contracting Parties undertake not to hinder in any way the effective exercise of this right." ${ }^{42}$

Since it is beyond the scope of this paper to analyze the current approaches to the modernization of the international system of protection of human environmental rights, ${ }^{43}$ here I merely point out that the regimes established under the European Convention and Aarhus Convention are of equel value from the perspective of developing the national legal system. Indeed, the practice of the European Court of Human Rights proves once again the decisive role of a strict international protection system in the evolution of the national legal order of transitional countries. However, these two Conventions are a part of the national legal system and have the same direct or indirect effect on its evolution.

\section{What is the hierarchy and influence of judicial acts on the overall legal practice of}

\section{Armenia?}

With the amendment of the Constitution, article 92 gave the Armenian Cassation Court a new legal status. It is defined as the "highest court instance in the Republic of Armenia, except for matters of constitutional justice, [...] which shall ensure uniformity in the implementation of the law." According to article 15 of the Judicial Code of the RA, the "reasoning in a decision of the Cassation Court of Armenia or the European Court of Human Rights in a case with certain factual circumstances (including the interpretation of the law) is binding for any court in the examination of a case with identical/similar factual circumstances, unless the latter court, by indicating solid arguments, justifies that such reasoning is not applicable to the factual circumstances at hand." It follows, then, that the ratio decidendi of judicial decisions in the legal system of Armenia are pointed out by the positive law.

\footnotetext{
${ }^{42}$ The applicants in a case submitted to the Court lived close to a nuclear power plant, which had applied for an extension of its operating period and also an increase in production. The question before the Court was whether the risks of living close to a nuclear plant were sufficient to apply Art. 6(1). The Court found it not applicable since the outcome of the proceedings at issue was not directly decisive for the right asserted by the applicants. The applicants could not show that they were exposed to a specific, imminent and serious danger.

${ }^{43}$ DE SILVA, L., WATES, J., "Globalizing Environmental Democracy: A Call for International Actions", available at <http://www.accessinitiative.org/resource/globalizing-environmental-democracy> (DLast retrieved on 7 December, 2012).
} 
When article 15 of the Judicial Code of Armenia was enacted (2007), I pointed out the artificial nature of the regulation and predicted the possibility of abuses and violations, regarding the peculiarities of judicial precedent in Armenia and the syncretism of the Armenian legal system. If we are guided by article 15 of the Judicial Code of Armenia the two lines of reasoning expressed in the decisions of the Cassation Court of Armenia between 30 October, 2010, and 1 April, 2011 may serve to further develop case law. However, case law has taken into consideration the opinion expressed in the judgment of 1 April, 2011.

The question about the hierarchical interrelation between the acts of the Cassation Courts of Armenia and the official clarifications of the CCC has no answer even in the RA Act on Legal Actions. However, the aim of adopting CCC Decision N 127 was to underline the position of Armenia's Judicial System on this issue.

The ongoing developments in judicial practice once again prove the vision of the Administrative Court of Armenia on the legal standing of NGOs. On 24 March, 2011 the Common Jurisdiction Court of First Instance of the Syunik region accepted the suit of 22 residents against the Armenian Water Sewerage Company, obliging it "1. to operate in compliance with obligations assumed by the contract, that is, to provide wastewater treatment and discharge; 2. to exclude any risk for the environment by promoting the health and well-being of human beings".

The Administrative Court of Armenia is currently considering lawsuit VD/4221/05/11, brought before the court by five residents from the Syunik region requiring the court to enforce the Ministry of Nature Protection to act according its legal competences. In my opinion this lawsuit will have a positive outcome for the plaintiffs as it is straightforwardly related to the previous case. It should be pointed out that NGOs widely use institutes of representation with significant results for regional residents.

\section{What are the possible alternatives?}

One of our suggestions for improving the draft on the amendments and addenda to the RA Environmental Impact Assessment Act was to reinforce the legal status and 
structure of the expert conclusion (EIA conclusion). ${ }^{44}$ In particular we suggested that the decision of the Ministry of Nature Protection on the acceptance or refusal of suggestions, remarks and objections provided by the public should be legally stipulated to be a structural part of the EIA conclusion. Another suggestion was to confer on whether NGOs' had the right of judicial appeal on any issue that matters in public participation. This kind of regulation will link the expert conclusion to the rights of participants (individuals, NGOs and etc.), hence generating legal opportunity to challenge the legality of acts.

I have found an analogous model functioning in Switzerland, where the right to challenge legal acts is accepted in cases subject to environmental impact assessment. ${ }^{45}$ The same kind of regulation is incorporated in the EU Directive and the obligation. It should be remembered that there is a mandate to approximate to its principles in the Eastern Partnership Roadmap (point C.5). ${ }^{46}$ considerate is crucial that the aforementioned principles be crucially regulated so as to ensure the right of concerned parties to have access to justice in environmental matters. Nevertheless, the standing of non-professional legal entities that have no interest in providing input into the decision will be excluded when they initiate groundless litigations. In my opinion the application of the criterion of sufficient interest is also justified from the empirical point of view (see, for example, the case of Teghout copper-molybdenum deposit which was initiated by the organization expressing no interest in decision-making).

According to paragraph 2 of article 2 of RA CAP "Administrative procedural norms stipulated in other laws should be in line with this Code", the inclusion of the respective norm in the sectoral law is not enough to ensure the unobstructed regulation of public relations. Therefore, the principles of granting access to justice to a variety of entities should be laid down in the RA CAP.

\footnotetext{
${ }^{44}$ An interview is available at $<$ http://www.ecolur.org/en/news/officials/lawyer-gor-movsisyan-billpassed-first-reading-at-parliemant-but-legally-not-substantiated/3334/> (Last retrieved on 11 December, 2011).

${ }^{45}$ German Advisory Council on the Environment. Id. pp. 6-7.

46 European Commission Joint Staff Working Document. Eastern Partnership Roadmap 2012-13: the bilateral dimension, pp. 36 .
} 


\section{CONCLUSION}

Although I have suggested that improving legislation is one way of clarifying the standing of NGOs in this field, perhaps the most promising way is case law, with the judges being granted the necessary discretion for each case. The provisions of the Aarhus Convention and the considerations on the fourth question above may serve as a point of departure in ensuring sufficient legal resolution of the NGOs legal standing before the court.

The issues of public interest litigation have been well scrutinized by Western legal literature. However, from the practical point of view the "modernization" of the problem in Armenia, and in other post Soviet Union countries, requires more profound research and pressure by NGOs, civil initiatives and citizens.

The view expressed in this article also attaches importance to the perspective of public policies and the readiness of economic entities to prove that their activities comply with the provisions of environmental legislation (which are sometimes too vague).

\section{BIBLIOGRAPHY}

- BACKES, C., ELIANTONIO, M., "The influence of the ECJ's case law on indirect effect in the Italian, German, Dutch and English administrative legal systems and its application by the national administrative courts", 2009, available in $<$ http://ssrn.com/abstract=1427255>.

- BONINE, J. E., "The public's right to enforce envronmental law”, in STEC, S. (ed.) Handbook on Access to Justice under the Aarhus Convention, Szentendre (Hungary), 2003.

- DARPÖ, J., "Justice through Environmental Courts? Lessons Learned from the Swedish Experience", available at $<\mathrm{http}$ :/www.jandarpo.se/inenglish.asp $>$.

- EBBESSON, J., “Access to Justice in Environmental Matters in the EU”, 2002.

- HYDE, C., International Law Chiefly as Interpreted and Applied by the United States (1), Moscow, 1950.

- KOCHARIAN, V. Commentaries to the Constitution of the Republic of Armenia, Yerevan, 2010. 
- KRAVCHENKO, S., "The Aarhus Convention and Innovations in Compliance with Multilateral Environmental Agreements", Colorado Journal of International Environmental Law and Policy, vol 18, n. 1, 2007.

- KRAVCHENKO, S., BONINE, J. E. "Interpretation of Human Rights for the Protection of the Environment in the European Court of Human Rights", Global Business and Development Law Journal, vol. 25, 2012.

- PRING, G., PRING, C. Greening Justice: Creating and Improving Environmental Courts and Tribunals, 2009

- VERDROSS, A., International Law, Moscow, 1959.

- VIÑUALES, J. E., "The resource curse - a legal perspective", Global Governance, 2010 , available in $<$ http://papers.ssrn.com/sol3/papers.cfm?abstract_id=1652739>. 